\title{
Influence of Lignohumate on tomato seeds germination and growth under inoculation with bacte- rial spot causative pathogen Xanthomonas vesicatoria
}

\author{
Nanuli Amashukeli \\ Dali Gaganidze \\ Neli Sturua \\ Shorena Kharadze \\ Tinatin Sadunishvili \\ Durmishidze Institute of Biochemistry and Biotechnology, \\ Agricultural University of Georgia, 240, David Aghmashenebeli \\ Alley, 0159 Tbilisi, Georgia
}

Abstract: Bacterial spot, caused by Gram-negative phytpathogenic bacteria Xanthomonas campestris pv. vesicatoria is one of the de vastating diseases, that causes significant decrease in tomato and peper yield and economic loss. With the aim of search of natural means against the diseases study has been conducted on the influence of immune stimulation preparation of plant origin Lignohumate AM on tomato protection from bacterial spot while seeds inoculation with disease causative pathogen $X$. vesicatoria. Inoculation of tomato seeds have been carried out with $X$. vesicatoria strains No2255 and No2256, isolated by us from bacterial spot diseased tomato leaves, collected in Kartli Region, Georgia in 2014-2015 years, as well as with Ref. strain NCPPB422. For the seeds inoculation $24 \mathrm{~h}$ grown on $2 \%$ potato agar culture $\left(10^{8} \mathrm{CFU} / \mathrm{ml}\right)$ washout suspensions were used. In some variants 4 hour water soaked seeds were simultaneously inoculated by $X$. vesicatoria different strains and treated with lignohumate during 1 hour at $24^{\circ} \mathrm{C}$. Control variant - intact seeds were soaked in sterile water during 5 hours at $24^{\circ} \mathrm{C}$. Some seeds before or simulatneously with bacteria inoculation were treated with $10 \%$ Lignohumate AM solution. As a result of inoculation with $X$. vesicatoria virulent strains the amount of grown seedlings decreased by $75 \%$ as compared to intact seeds. Treatment of seeds with Lignohumate, simultaneously or before the inoculation by $X$. vesicatoria, resulted in 3.0-3.5 times increase in growth and development as compared to untreated inoculated seeds. The results indicate on efficiency of lignohumate AM in protection of tomato seeds from $X$. vesicatoria infection.

Key Words: tomato bacterial spot, Xanthomonas vesicatoria, Lignohumate

Accepted for publication: 10 December 2018

E-mail: t.sadunishvili@agruni.edu.ge

\section{INTRODUCTION}

One of the deliterarious diseases of tometo and peper, bacterial spot is caused by Gram negative phytopathogen Xanthomonas campestris pv. vesicatoria (Doidge) Dye. Xanthomonas vesicatoria infects tomato seeds, all aboveground parts (foliages and stems) and green fruits, as a result of which black spots are formed on them [Bulletin OEPP/EPPO Bulletin, 2013].

The infection occurs after mechanical injury, and is displayed in angular, irregular-shaped spots on foliages and in slightly developed scabby spots on fruits, resulting in defoliation, diseased fruits and reduction of yield.

$X$. vesicatoria survive in the infected remains of tomato plant in winter. Conditions for the development of the disease are temperature $24-300^{\circ} \mathrm{C}$, high humidity and rain. The bacteria dissemination is caused by wind or irrigation, as well as some agrotechnic measures. The seed is also a means of survival and spread of pathogen. $X$. vesicatoria retain the patogenicity on seeds for 2 years and can be transplanted from the diseased seeds to healthy ones, resulting in decrease of tomato plants and economic loss. The phytopathogen also can accumulate in soil where they are able to survive during a year [Jones et al., 2000].

Currently, integrated management, including agrotechnical measures, chemical control and resistant plant selection are applied to fight the bacterial spot disease. There are no resistant plants to pathovars of Xanthomonas campestris pv. vesicatoria. Agrotechnical measures such as the selection of healthy transplant, burning of vegetation debris, three or more year's rotation of crops are almost ineffective. Copper salts, especially insoluble in water are effective for treatment of aboveground parts of plants [Marco and Stall, 1983]. However, reliance on copper pesticides is questioning because of the formation of tolerant strains [Voloudakis et al., 2005], as well as phytotoxicity [Momol et al., 2002] and soil contamination, especially when applied in high concentrations to overcome the adverse conditions of weather. The possibility to use alternative control methods has been demonstrated using systemic aquired resistance (SAR) inducers that cause activation of plant protection reactions [Louws et al., 2001; Obradovich et al., 2002].

Actigard, a systemic compound containing the active ingredient acibenzolar-S-methyl, exhibits a unique 
mode of action that mimics the natural systemic activated resistance (SAR) response found in many plants (Gao et al., 2014). Actigard, that provides protection against bacterial speck and bacterial spot in tomatoes, and blue mold in tobacco has received approval for use in Canada [https://www.fruitandveggie.com/vegetables/actigard-approved-for-use-in-canada-10313].

Due to ecological challenges, for developent of modern agriculture, it is important to search natural, biological preparations/means against tomato bacterial spot and plant bacterial diseases in common. One such alternative could be application of bacterial viruses [Jones et al., 2007, Ghudumidze et al., 2005, Sadunishvili, Kvesitadze, 2015].

Lignohumate is a humic fertilizer obtained through oxidation/hydrolytic destruction of lignin-containing raw materials. This preparation as advertized possesses a broad spectrum of activity on plants: is growth stimulator; improves vitality and health condition of plant; supports resistance against stressing factors; increases high and low-temperature stability; strengthens immunity of plants; Lignohumate increases efficiency of processing of seed material, suppression of pathogens propagation (http://lignohumate.co.uk; https://www. amagro.com). Lignohumate AM is enriched with trace quantities of basic micro-elements in the form of chelates [Amagro Humic Substances https://www.amagro. com/lignohumate-am.html].

It was reported that Lignohumate promotes growth and development of bacteria, such as Pseudomonas, Agrobacterium, Flavobacterium, Bacillus and Arthrobacter. It's stimulatory effect on nitrogen-fixing bacteria at minor concentrations, and inhibition of growth of some bacteria species at high concentrations have been demonstrated [Tugarinov et al., 2009]. Lignohumate was shown to promote growth of soil microorganisms [Lipsa et al., 2012]. There is no literature on the ability of this natural preparation to plant protection from bacterial diseases caused by phytopathogens.

The aim of the present paper is to study the potential of Lignohumate to prevent tomato from bacterial spot while seeds inoculation with causative pathogen $X$. vesicatoria.

\section{MATERIAL AND METHODS}

Studies have been carried out on seeds of Georgian variety Pink tomato. Visually healthy seeds were checked on their germinability.

The commercial preparation "Lignohumate AM" (https://www.amagro.com/lignohumate-am.html) were applied in experiments. 10\% Sterile water solution of the preparatuion was used for seed treatment.

Initially about 500 seeds of tomato were treated by desinfectant solution, commrcial ACE at 1:3 ratio during 10 minutes. After that, seeds were washed 10 times with sterile water and dried on sterile filter paper in laminar box. For germination, seeds in amount 50-50 for each variant of experiment were soaked in sterile water or in $10 \%$ sterile water solution of Lignohumate AM, according to manufacturer's instruction, during 4 hours at $24^{\circ} \mathrm{C}$.

For inoculation of seeds $X$. vesicatoria strains No2255 and No2256, isolated by us from bacterial spot diseased tomato leaves, collected in Kartli Region, Georgia in 2014-2015 years, as well as Ref. strain NCPPB422 were used. Soaked in sterile water or Lignohumate $10 \%$ solution seeds during 4 hours were inoculated by X.vesicatoria strains $24 \mathrm{~h}$ grown on $2 \%$ potato agar culture $(108 \mathrm{CFU} / \mathrm{ml})$ washout suspensions during 1 hour at $24^{\circ} \mathrm{C}$. In some variants 4 hour water soaked seeds were simultaneously inoculated by $X$. vesicatoria different strains and Lignohumate treated during 1 hour at $24^{\circ} \mathrm{C}$. Control variant - instact seeds were soaked in sterile water during 5 hours at $24^{\circ} \mathrm{C}$.

Treated in different ways tomato seeds were sown in separate pots with soil and placed at desirable for $X$. vesicatoria conditions, in particular $24-28^{\circ} \mathrm{C}$ temparature at good aeration. High humidity was maintained by intensive watering.

\section{RESULTS AND DISCUSSION}

Tomato seedlings grown from: intact seeds, $X$. vesicatoria three different strains inoculated seeds; Lignohumate AM preptreated inoculated seeds; seeds simultaneously inoculated and treated with Lignohumate AM (Fig. 1-4).

As seen, tomato seedlings, grown from inoculated by $X$. vesicatoria three different strains are far behind in growth both in quantity or quality as compared to seedlings from intact seeds. On the contrary, seedlings grown from Lignohumate AM treated seeds, either before or simultaneously with inoculation do not differ are almost similar with intact seeds grown seedlings. In particular, seedlings grown from $X$. vesicatoria inoculated and Lignohumate treated seeds were almost of the same length $(24-26 \mathrm{~cm})$ as controls $(25 \mathrm{~cm})$, on the contrary to pathogen inoclutaed seedlings, which were of $12.5-13 \mathrm{~cm}$.

Numeral data of seedlings grown from $X$. vesicatoria inoculated and Lignohumate AM treated seeds is 


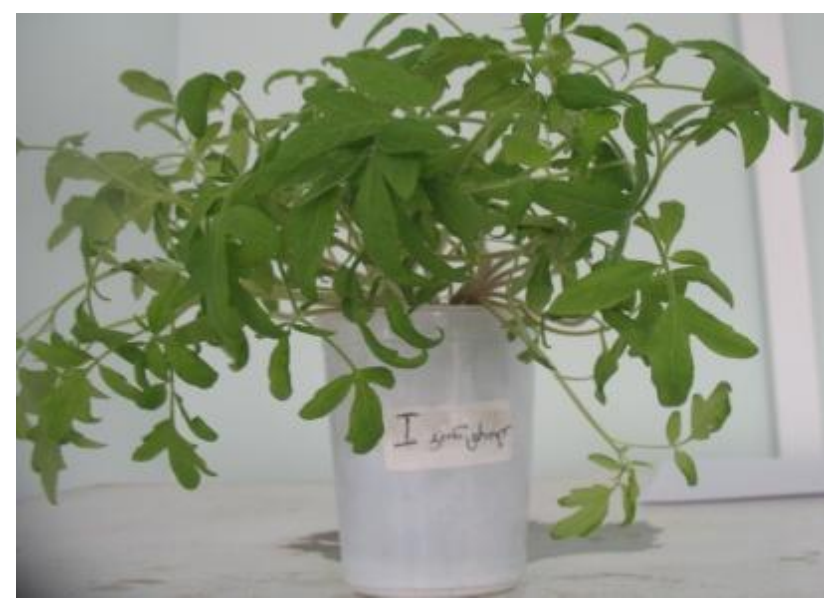

Figure 1. Tomato seedlings grown from intact seeds.

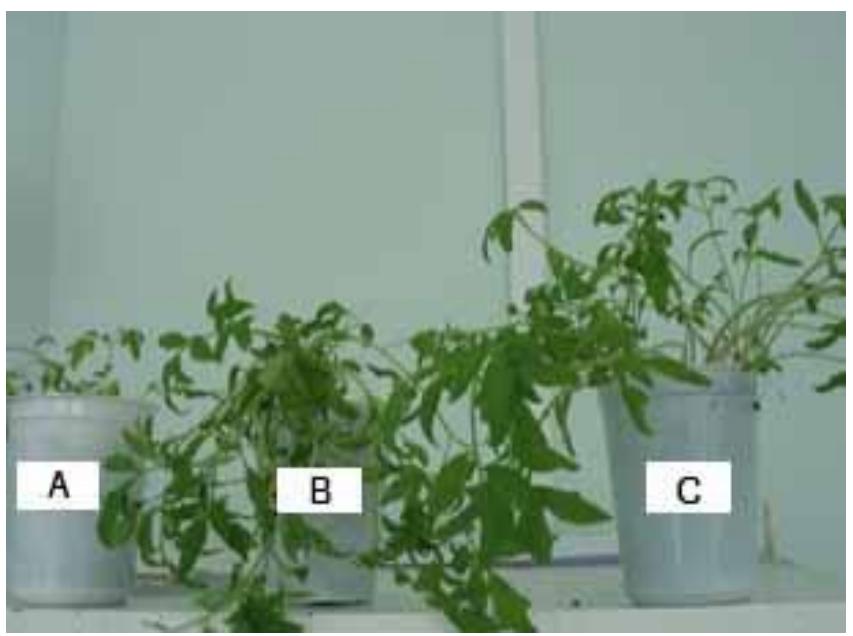

Figure 2. Tomato seedlings, grown from $X$. vesicatoria strain NCPPB 422 inoculated seeds: A. $X$. vesicatoria NCPPB 422 inoculated; B. Pretreated by Lignohumate $\mathrm{AM}$ before inoculation; $\mathrm{C}$. Inoculated and treated by Lignohumate AM simultaneously.

represented on Fig. 5. As seen, 37 seedlings were grown from 50 tomato intact seeds (Fig. 5.1). As a result of inoculation with different $X$. vesicatoria strains, only 8 or 9 seedlings were grown (Fig. 5.2, 5.5, 5.8). Amount of healthy seedlings grown from $X$. vesicatoria different strains inoculated seeds has increased to 30-33 when seeds were treated by Lignohumate AM before (Fig. 5.3, 5.6, 5.9) or simultarneously (Fig. 5.4, 5.7, 5.10) with inoculation. At the same time the protective effect of the Lignohumate is a little better in case of application before bacterial inoculation.

Thus, as a result of inoculation with $X$. vesicatoria virulent strains, the amount of grown seedlings decreased by $75 \%$ as compared to intact seeds. Treatment of seeds with Lignohumate simultaneously or before the inoculation by $X$. vesicatoria, resulted in 3.0-3.5

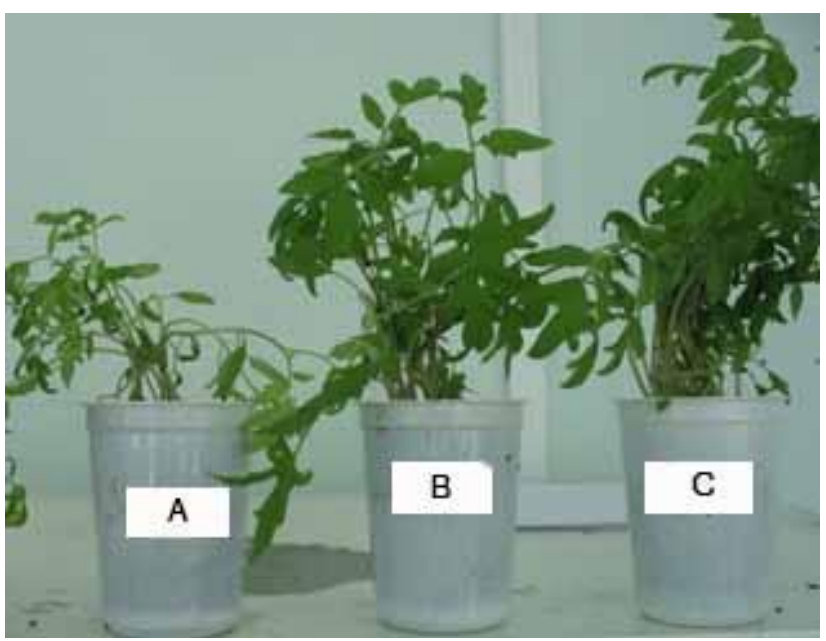

Figure 3. Tomato seedlings grown from $X$. vesicatoria strain \#2255 inoculated seeds: A. $X$. vesicatoria No2255 inoculated; B. Pretreated by Lignohumate AM before inoculation; C. Inoculated and treated by Lignohumate AM simultaneously.

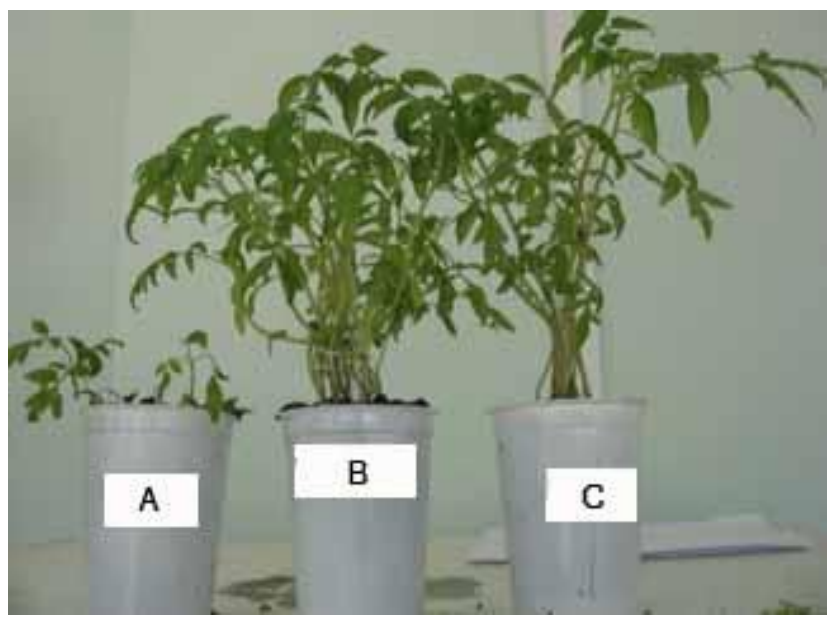

Figure 4. Tomato seedlings grown from $X$. vesicatoria strain No2256 inoculated seeds: A. X. vesicatoria No2256 inoculated; B. Pretreated by Lignohumate AM before inoculation; $\mathrm{C}$. Inoculated and treated by Lignohumate AM simultaneously.

times increase in growth and development as compared to untreated inoculated seeds. These results indicate on efficiency of lignohumate AM in protection of tomato seeds from $X$. vesicatoria infection. Prevention from $X$. vesicatoria infection could be explained by activation of plant natural protective mechanisms by the Lignohumate AM. This is first experimental data on Lignohumate AM property to protect tomato from $X$. vesicatoria infection, and in common, to protect plants from phytopathogens infection. 


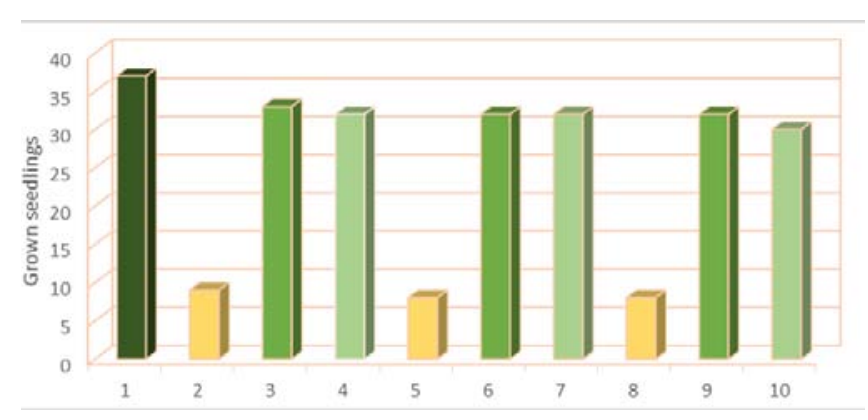

Figure 5. Influence of Lignohumate AM treatment on tomato seedlings growth from $X$. vesicatoria inoculated seeds: 1 . Intact seeds; $2 . X$. vesicatoria Ref. strain NCPPB 422 inoculated seeds; 3 . $X$. vesicatoria Ref. strain NCPPB 422 inoculated seeds after Lignohumate AM pretreatment; 4. X.vesicatoria Ref. strain NCPPB 422 inoculated and simultaneously Lignohumate AM treated seeds; 5 . $X$. vesicatoria strain \#2255 inoculated seeds; 6. $X$. vesicatoria strain \#2255 inoculated seeds after Lignohumate AM pretreatment; 7. X. vesicatoria strain \#2255 inoculated and simultaneously Lignohumate AM treated seeds; 8. X. vesicatoria strain \#2256 inoculated seeds; 9. X. vesicatoria strain \#2256 inoculated seeds after Lignohumate AM pretreatment; 10. $X$. vesicatoria strain \#2256 inoculated and simultaneously Lignohumate AM treated seeds.

\section{CONCLUSIONS}

Lignohumate AM treatment provides significant protection of tomato seeds from $X$. vesicatoria infection. The preparation is effective when applied as preliminary treatment as well as simultaneously to inoculation. Quantitative evaluation is $84-87 \%$ healthy seedlings as compared to $18-20 \%$ seedlings grown from $X$. vesicatoria inoculated seeds without Lignohumate.

\section{REFERENCES}

Amagro Humic Substances: https://www.amagro.com

Balogh, B. (2002) Strategies for improving the efficacy of bacteriophages for controlling bacterial spot of tomato. M.S. thesis. University of Florida, Gainesville.

Fruit \& vegetable: https://www.fruitandveggie.com/ vegetables/actigard-approved-for-use-in-canada- 10313

Gao QM, Kachroo A, Kachroo P. (2014) Chemical inducers of systemic immunity in plants. J Exp Bot. 65(7): 1849-55.

Ghudumidze N., Alavidze Z., Chkonia I. Eliashvili P., Giorgobiani N., Shapovalova N., Meipariani A., Sadunishvili T. (2007) Effective controlling of bacteri- al spot in tomato with bacteriophage. Proc. Georgian Acad. Sci., Biol. Ser. B, 5(1): 8-11.

Jones J.B., Jackson L.E., Balogh B., Obradovic A., Iriarte F.B. and. Momol M.T. (2007) Bacteriophages for Plant Disease Control. Annu. Rev. Phytopathol. 45: 245-262.

Jones J.B., Bouzar, H., Stall, R. E., Almira, E.C., Roberts, P., Bowen, B.W., et al. (2000) Systematic analysis of xanthomonads Xanthomonas spp. associated with pepper and tomato lesions. International Journal of Systematic Bacteriology, 50: 1211-1219.

Lignohumate: http://lignohumate.co.uk;

Lipsa F.D., Ulea E., Morari E.C., Gales D., Arsene I.C. (2012) Effect of lignohumate (humic fertilizer) on soil microorganisms. Lucrări Ştiinţifice, seria Agronomie55 (2): 253-256.

Louws, E. J., Wilson, M., Cambell, H. L., Cuppels, D. A., Jones, J. B., Shoemaker, P. B., Sahin, F., \& Miller, S. A. (2001) Field control of bacterial spot and bacterial speck of tomato using a plant activator. Plant Disease, 85: 481-488.

Marco, G. M., \& Stall, R. E. (1983) Control of bacterial spot of pepper initiated by strains of Xanthomonas campestris pv. vesicatoria that differ in sensitivity to copper. Plant Disease, 67: 779-781.

Momol MT., Jones JB., Olson SM., Obradovic A., Balogh B. King P. (2002) Integrated mmanagement of bacterial spott on tomato in Florida. Rep Pp110, EDIS. Inst. Food Agric. Sci., Univ. Fl34.

Obradovic, A., Jones, J. B., Momol, M. T., Olson, S. M., King, P. C., and Balogh, B. (2002) Management of tomato bacterial spot in the field by foliar applications of bacteriophages and SAR inducers. Phytopathology, 92: 60.

Sadunishvili T., Kvesitadze E., Kvesitadze G. (2015) Xanthomonas vesicatoria specific virus and its potential to prevent tomato bacterial spot disease. Chapter in: Nanotechnology to Aid Chemical and Biological Defence. T.A. Camesano Ed., Springer, The Netherlands, 333-372.

Tugarinov L.V. et al. (2009) - available from: www. amagro.com/content/file/Doklad_tug_c z. pdf.

Voloudakis A.E., Reignier T.M., Cooksey D.A. (2005) Regulation of resistance to copper in Xanthomonas axonopodis vesicatoria. Appl Environ Microbiol. 71: 782-789. 


\section{Bakterial ləkə tərədən patogen Xanthomonas vesicatoria ilo yoluxmüş tomat toxumlarının cücərmə və böyüməsinə Lignohumatın təsiri}

Nanuli Amaşukeli

Dali Gaganidze

Neli Sturua

Şorena Kharadze

Tinatin Sadunishvili

Durmişidze Biokimya vo Biotexnologiya İnstitutu, Kand tasarrüfatı Universiteti, Gürcüstan, 240, David Ăgmaşenebeli xiyabanı, 0159 Tbilisi, Gürcüstan

Qram-mənfi fitopatogen Xanthomonas campestris pv. vesicatoria bakteriyasının törətdiyi bakterial ləkə tomat və bibərin məhsuldarlığını əhəmiyyətli dərəcədə azaldan və iqtisadi itkilərlə nəticələnən dağıdıcı xəstəliklərdən biridir. Xəstəliyə qarşı təbii üsulların axtarışı üçun tomat toxumların $X$. vesicatoria xəstəlik törədici patogeni ilə yoluxdurduqdan sonra bakterial ləkə xəstəliyinə bitki mənşəli immun stimulyasiya edən Lignohumate AM istifadə etməklə təsir göstərilmişdir. Tomat toxumlarının inokulyasiyası üçün 2014-2015-ci illərdə Gürcüstanın Karli regionunda bakterial ləkə xəstəliyinə yoluxmuş tomat bitkisinin yarpaqlarından ayrılmış $X$. vesicatoria növünün No2255, No2256 ştammlarından vo həmçinin NCPPB422 referens ştmmdan istifadə edilmişdir. Toxumların inokulyasiya etmək üçün 24 saat $2 \%$ kartof aqarlı mühitdə $\left(10^{8} \mathrm{~K} \partial \mathrm{V} / \mathrm{ml}\right)$ yuycu suspensiya tətbiq edilmişdir. Bəzi variasiyalarda 4 saat su ilə isladılmış toxumlar dərhal $X$. vesicatoria bakteriyasının müxtəlif ştammları ilə yoluxdurulmuş, və 1 saat $24^{\circ} \mathrm{C}$ də Lignohumate ilə işlənmişdir. Kontrol variant olraq işlənməmiş toxumlar steril su ilə 5 saat ərzində $24^{\circ} \mathrm{C}$-də isladılmışdır. Bəzi toxumlar inokulyasiya ilə eyni vaxtda $10 \%$ Lignohumate ilə işlənilmişdir. $X$. vesicatoria virulent ştammı ilə inokulyasiya nəticəsində cücərən toxumların sayı kontrolla müqayisədə $75 \%$ azalmışdır. Toxumlara $X$. vesicatoria inokulyasiya edilərkən eyni vaxtda və ya öncədən Lignohumate ilə işlənməsi nəticəsində cücərmə və inkişaf işlənməmiş toxumlarla müqayisədə 3.0-3.5 dəfə artmışdır. Nəticələr tomat toxumlarının $X$. vesicatoria infeksiyalarında Lignohumate AM istifadəsinin mühafizəedici təsirini göstərir.

Açar sözlor: tomat bakterial laka, Xanthomonas vesicatoria, Lignohumate
Влияние Lignohumate на всхожесть и рост семян томата, при инокуляции возбудителем бактериальной пятнистости Xanthomonas vesicatoria

Nанули Амашукели

Дали Гаганидзе

Nели Стуруа

Шорена Харадзе

Тинатин Садунишвили

Институт Биохимии и Биотехнологии им. Дурмишидзе, Грузинский Аграрный Университет, аллея Давида Агмашеневели 240, Тбилиси 0159, Грузия.

Бактериальная пятнистость, вызванное граммотрицательной фитопатогенной бактерией Xanthomonas campestris pv. vesicatoria является одной из разрушительных болезней, которая приводит к значительному снижению продуктивности томата и перца и экономическим потерям. С целью поиска природных средств против болезней проводилось исследование по влиянию иммуностимулирующего препарата растительного происхождения Lignohumate AM на защиту томата от бактериальной пятнистости, при инокуляции семян патогеном $X$. vesicatoria. Инокуляция семян томата проводилась штаммами $X$. vesicatoria №2255 и №2256, изолированными нами из пораженных бактериальной пятнистости, листьев томата, собранных в регионе Карли Грузии в 2014-2015 гг., также как Ref. штаммом NCPPB422. Для инокуляции семян использовали промывочные суспензии 24 ч. культуры бактерии, выращенных на среде $2 \%$ картофельного агара $\left(10^{8} \mathrm{CFU} / \mathrm{ml}\right)$ омывающих суспензий. В некоторых вариантах семена, замоченные 4 ч. были одновременно инокулированы $X$. vesicatoria различных штаммов и обработаны Lignohumate в течении 1 ч. при $24^{\circ} \mathrm{C}$. Контрольный вариант - интактные семена, замоченные в стерильной воде в течении 5 ч. при $24^{\circ} \mathrm{C}$. Некоторые семена до или одновременно с бактериальной инокуляцией были обработаны $10 \%$ раствором Lignohumate AM. В результате инокуляции $X$. vesicatoria вирулентным штаммом количество растущих семян снижалось на $75 \%$ по сравнению с интактными семенами. Обработка семян Lignohumate, одновременно или до инокуляции $X$. vesicatoria приводила к 3.0-3.5 paзовому повышению роста и развития по сравнению с необработаными семенами. Результаты указывают на эффективность Lignohumate AM в защите семян томата от инфекцирования $X$. vesicatoria.

Ключевые слова: бактериальная пятнистость томama, Xanthomonas vesicatoria, Lignohumate 